\title{
Local Wisdom Value in Javanese Cultural in "Serat Tripama” by KGPAA Mangkunegara IV
}

\author{
N Priyatiningsih ${ }^{1}$, L Isnawati $^{2}$ \\ Univet Bantara University, Sukoharjo, Indonesia \\ urpenipriyatiningsih@gmail.com ${ }^{1}$, lusiisnawati@gmail.com²
}

\begin{abstract}
This research aimed: (1) to describe the content of Serat Tripama by KGPAA Mangkunegara IV and (2) to reveal javanese cultural local wisdom values in Serat Tripama by KGPAA Mangkunegara IV. This study was a qualitative research with literary sociological approach and descriptive research method with library study being technique of collecting data and triangulation being technique of validating data. Technique of analyzing data used encompassed four stages: data collection, data reduction, data display, and conclusion drawing. The result of research showed that Serat Tripama by KGPAA Mangkunegara IV contained seven pada (verses) with tembang dhandanggula the content of which is intended to soldiers. In addition, the song (tembang) told about three puppetry figures: Patih Suwanda, Kumbakarna, and Basukarna. Overall, Serat Tripama contained twelve javanese cultural local wisdom values applicable to daily life: truth, responsibility, noble character, nationalism, state defense, leadership and justice, caring about environment, loving to homeland, honesty and trusteeship, returning the favor, holding tightly on principle, and truth defender. The conclusion was that Serat Tripama contained an instruction to soldiers to imitate the knight local wisdom values of three figures: Sumantri, Kumbakarna, and Basukarna, and twelve javanese cultural local wisdom values applicable to daily life.
\end{abstract}

Keywords: value, local wisdom, serat

\section{INTRODUCTION}

Javanese poetry particularly tembang macapat, in addition to serving as entertainment, is also considered as having such power as spell (magic formula), evil averter, and etc. Therefore, tembang macapat is often sung collectively in certain encounters such as birth, wedding, important village day, and etc. So, learning tembang macapat constituting the part of Javanese culture can be called learning Javanese culture. As same as Javanese culture ideology, state policy must be fair and equitable [1].

One of old manuscript heritages containing education tenet is Serat Tripama by KGPAA Mangkunegara IV (1811-1881, crowned in 1853). Serat Tripama is still popular in Javanese cultural environment until today [1]. Javanese people pay very much attention to the tenets contained in Serat Tripama to be practiced into their life. An analyzed of this literary approach needs more combination of structuralism which deals with the unity of intrinsic elements and the sociology of literature which concerns with the extrinsic elements [2]. 
One of the main reason of this research is to proof the power as spell on the Javanese philosophy of life full of wisdom [3]. Considering this background, the author is interested in revealing the role of Serat Tripama in javanese cultural local wisdom.

From the background above, the author formulates the problems of research as follows: What is the content of Serat Tripama by KGPAA Mangkunegara IV? What are local wisdom values in Javanese cultural contained in Serat Tripama by KGPAA Mangkunegara IV?

Considering the problem studies, the objectives of research are:

1). To describe the content of Serat Tripama by KGPAA Mangkunegara IV, and 2). To reveal the local wisdom values in Javanese cultural contained in Serat Tripama by KGPAA Mangkunegara IV.

\section{METHOD}

The theory employed in this research was the one concerning value concept, local wisdom, cultural, javanese cultural, letter/ serat, and tembang as well as tembang macapat. Javanese culture is a form of character actualization that is shown in the life of the Javanese community [4]. Javanese cultural forms have a wide variety, it is important to analyze and deeply recognize the form of culture that has strength. the results of the analysis can be implemented as important material that must be mastered by the younger generation through education [5]. Characters education can be implemented through learning strategies to increase the value of culture to be more easily accepted. Environmental factors in the context of character education have a very important role to changes student behavior. As a result of the character education process are very determined by these environmental factors [6]. In other words the formation and engineering of the environment which includes the physical environment and school culture, school management, curriculum, educators, and teaching methods.\#

This study was a qualitative research with literary sociological approach and descriptive research method with library study being technique of collecting data and data triangulation being technique of validating data [7]. Technique of analyzing data used encompassed four stages: data collection, data reduction, data display, and conclusion drawing.

\section{RESULT AND DISCUSSION}

\subsection{Content of Serat Tripama by KGPAA Mangkunegara IV}

Serat Tripama was created by KGPAA Mangkunegara IV consisting of seven verses (pada) of tembang macapat or tembang dhandhanggula and every pupuh consists of some verses. Its language structure is so simple that its meaning is acceptable, and its words are beautiful so that its content is understandable [8]. Serat Tripama is the message written in tembang macapat dhandhanggula the content of which is an instruction intended to soldiers in order to imitate local wisdom values in javanese cultural and attitudes of three puppetry knight figures: Sumantri, Kumbakarna, and Basukarna. Character education is based on ethical values that everyone can agree to. Education through the environment and culture must provide opportunities to develop and explore their potential and give appreciation for the potential they have, respect decisions and support children in making decisions [9]. 


\subsection{Local Wisdom Values in Javanese Cultural in Serat Tripama}

The essence of Javanese culture for nation-building as local wisdom to face of the global era as forms the resilience of the nation's culture from the local cultures strength [10]. Tembang macapat Dhandhanggula in Serat Tripama by KGPAA Mangkunegara IV mandates local wisdom values that should be a role model to its readers. Local wisdom values intended are, among others:

1. Truth

Sumantri took the truth way by qualifying to be a state's servant because to be a soldier, an elected person is needed.

2. Responsibility

Sumatri is a knight obedient to command and aware of his obligation.

3. Noble character

"Guna kaya purune den antepi, nuhoni trah utama" (his merits, integrated into three matters: smart, capable and brave (with which) he is preoccupied, fulfilling the local wisdoms of excellent descent.

4. Nationalism

When Maespati soldiers ran away from a battle in Alengka, Patih Suwanda gave stringent warning that the soldiers were prohibited from running away from battle field.

5. State defense

Patih Suwanda went to wage ware aiming not to seek for popularity but to defend his state from enemies and Alengka soldiers' attack.

6. Leadership

Kumbakarna had natural leadership feeling because a leader's spirit must have the feeling to protect and shelter the state and the people he leads. Kumbakarna warned Rahwana not to perform battle because war will result in damage and will threat his people's safety. A good leader should think of his people's safety as well, rather than satisfying his arrogance and egoism only in order to achieve all of his desires regardless the consequence and risk he will assume later. In turn, all of these will harm himself and his people.

7. Caring about Environment

After Kumbakarna saw Anoman burning his palace, he felt infuriated at his damaged kingdom environment. Kumbakarna was aware that environment is inseparable from life.

8. Loving to homeland

Loving to homeland was shown by two knights: Kumbakarna and Karna. His loving to homeland kept Kumbakarna struggling and going to wage war to face his enemies regardless their size and strength.

9. Honesty and trusteeship

Kumbakarna was a honest and trustable person in safeguarding his state; therefore he obeyed his brother (Rahwana)'s instruction to fight against Rama.

10. Returning the favor

Karna realized that his entire life from childhood to adulthood changed considerably. In Astina, he was the one lacking of affection but he became the pride; from an ordinary man he was then appointed by Duryudhana to be the king of Angga and he got all of these owing to Duryudhana's love and merit.

11. Holding tightly on his principle

Karna was the one undergoing various life principles firmly and sturdily, for example, Karna admitted that Kunthi is his biological mother.

12. Truth Defender 
Karna insisted to make Baratayudha war conducted because if the war did not occur, the truth would never be able to defeat the evil.

Those cultural values contained in the tembang macapat are manifestations of the cultural richness of the Javanese community [11]. As a cultural product, it is important to be implemented in an integrated and continuous manner in educational curriculums development. Multiplier effect from forming positive character of child will be seen from daily life, including society mindset in education. The higher character quality will certainly foster a strong desire to improve the quality of the nation. Best time to develop characters if it starts from an early age use an environment potency [12]. Character education is an important system for developing personality values that include relationships with oneself, towards the surrounding environment and relationships to God Almighty where all of them are formed from an understanding of what is seen, felt, and heard [13].

\section{CONCLUSION}

Considering the discussion related to content and local wisdom values in Javanese cultural contained in Serat Tripama by KGPAA Mangkunegara IV, the following conclusions could be drawn:

1. Content of Serat Tripama by KGPAA Mangkunegara IV

Serat Tripama consisted of 7 pada of tembang macapat packaged into tembang dhandhanggula consisting of several verses in its every pupuh. Serat Tripama contains role modeling given by three puppetry figures: Patih Suwanda, Kumbakarna, and Basukarna. Those three figures had kindness applicable to a variety of community's lives, particularly to soldiers fighting for defending their beloved countries.

2. Local wisdom values in Javanese Cultural in Serat Tripama

Tembang macapat Dhandhanggula in Serat Tripama by KGPAA Mangkunegara IV mandated local wisdom values in Javanese cultural that should be role model to their readers. In relation to its local wisdom values in Javanese cultural, it can be concluded that overall Serat Tripama contained twelve local wisdom values in Javanese culture applicable to daily life: truth, responsibility, noble local wisdom values, nationalism, state defense, leadership and justice, caring about environment, loving to homeland, honesty and trusteeship, returning the favor, holding tightly on principle, and truth defender.

\section{REFERENCES}

[1] H. Bratasiswara, Tripama Piwulang Budi Luhur. Surakarta: Kantor Reksa Pustaka, 1998.

[2] S. Endraswara, Metodelogi Penelitian Sastra. Yogyakarta: PT Buku Seru, 2011.

[3] S. Endraswara, Falsafah Hidup Jawa. Yogyakarta: Cakrawala, 2016.

[4] Kasihadi, Landasan Pendidikan Karakter. Semarang: IKIP PGRI Semarang Press, 2011.

[5] K. P. Nasiona, Pendidikan Karakter di Sekolah Menengah Pertama. Jakarta: Kementrian Pendidikan Nasional. Direktorat Jendral pendidikan Dasar. Direktorat pembinaan Sekolah Menengah Pertama, 2011.

[6] D. Kusuma, Pendidikan Karakter: Kajian Teori dan Praktik di Sekolah. Bandung: PT Remaja Rosdakarya, 2011.

[7] L. J. Moleong, Metodelogi Penelitian Kualitatif. Bandung: Remaja Rosdakarya, 2012.

[8] P. Rama and Ageng, Kebudayaan Jawa. Yogyakarta: Cahaya Ningrat, 2007. 
[9] J. Permana, Pendidikan Karakter Kajian Teori dan Praktik di Sekolah. Bandung: PT Remaja Rosdakarya, 2011.

[10] J. Permana, Pengkajian Sastra Jawa. Yogyakarta: Pura Pustaka, 2009.

[11] Rustopo, Jawa Sejati. Yogyakarta: Ombak, 2007.

[12] A. Salahudin, Metode Pendidikan. Bandung: CV Pustaka Setia, 2011.

[13] Soegeng, Landasan Pendidikan Karakter. Semarang: IKIP PGRI Semarang Press, 2013. 